\title{
PENDIDIKAN KARAKTER: SEBUAH UPAYA KOLEKTIF
}

\author{
Yati Budiarti \\ Politeknik Negeri Kesehatan Kemenkes Tasikmalaya \\ yatibudiarti@student.upi.edu
}

\begin{abstract}
ABSTRAK
Pendidikan karakter merupakan tanggung jawab bersama di setiap ruang lingkup pendidikan. Institusi pendidikan, seperti sekolah, keluarga dan masyarakat memiliki peran penting dalam pendidikan karakter. Untuk itu, pendidikan karakter di Indonesia membutuhkan kerja kolektif yang melibatkan semua elemen bangsa. Pendidikan nilai karakter dapat dilihat pada dua latar, yaitu pada latar makro dan pada latar mikro. Latar makro bersifat nasional yang mencakup keseluruhan konteks perencanaan dan implementasi pembinaan nilai karakter yang melibatkan seluruh pemangku kepentingan. Secara makro pembinaan karakter terdiri dari tiga tahap yaitu: perencanaan, pelaksanaan dan evaluasi hasil. Kajian ini menekankan bahwa peran keluarga, sekolah dan masyarakat merupakan kolaborasi penting dalam pendidikan karakter. Oleh sebab itu, sangat direkomendasikan adanya kerjasama yang secara nyata diwujudkan dalam proses pendidikan karakter.
\end{abstract}

\section{Kata Kunci: Pendidikan, Karakter, Keluarga, Sekolah, Masyarakat}

\section{PENDAHULUAN}

Dunia pendidikan di Indonesia saat ini sedang memasuki masa-masa yang pelik. Anggaran pendidikan yang sangat besar disertai berbagai program terobosan belum mampu memecahkan persoalan mendasar dalam dunia pendidikan, yaitu bagaimana mencetak lulusan yang unggul, beriman, bertaqwa, profesional, dan berkarakter, sebagaimana tujuan pendidikan dalam UU RI Nomor 20 tahun 2003 tentang Sistem Pendidikan Nasional. Dalam Bab II, Dasar, Fungsi, dan Tujuan, Pasal 3, UU RI Nomor 20 tahun 2003 tentang Sistem Pendidikan Nasional: disebutkan bahwa Pendidikan Nasional berfungsi mengembangkan kemampuan dan membentuk watak serta peradaban bangsa yang bermartabat dalam rangka mencerdaskan kehidupan bangsa, bertujuan untuk mengembangkan potensi peserta didik agar menjadi manusia yang beriman dan bertaqwa kepada Tuhan Yang Maha Esa, berakhlak mulia, sehat, berilmu, cakap, kreatif, mandiri, dan menjadi warga negara yang demokratis serta bertanggung jawab. Jika bangsa ini konsisten dan mempunyai tekad yang kuat untuk mengutamakan pembinaan karakter, tentu hal tersebut bisa direalisasikan. Syaratnya, pembinaan karakter harus dilakukan secara terpadu, yaitu di lingkungan keluarga, sekolah, dan masyarakat. Dengan desain demikian, diharapkan pembinaan karakter akan senantiasa hidup dan sinergi dalam setiap rongga pendidikan. Sejak anak lahir atau bahkan mulai dari dalam kandungan, ketika berada di lingkungan sekolah, kembali ke rumah, dan bergaul dalam lingkungan sosial masyarakatnya, akan selalu menjadi tempat bagi anak-anak untuk belajar, mencontoh, dan mengaktualisasikan nilai-nilai yang dipelajari atau dilihatnya.

\section{Makna Karakter}

Karakter dapat diartikan sebagai watak, sifatsifat kejiwaan, akhlak atau budi pekerti yang membedakan seseorang dengan orang lain. Karakter bukan sekadar tentang bagaimana melakukan hal yang benar dalam arti etis, akan tetapi lebih dari itu yakni melakukan pekerjaan dengan sebaik mungkin (Davidson, Lickona 
dan Khmelkov dalam Nucci dan Narvaez, 2016, hlm. 541). Plutarch berpendapat bahwa "Character is simply habit long continued", Aristoteles berpendapat bahwa "We are what repeatedly do. Excellen, then, is not an act, but a habit", sedangkan Arthur Wellesley berpendapat bahwa "Habit is ten times nature" (Daryanto \& Darmiatun, 2013). Menurut Suyanto (2010) karakter adalah cara berpikir dan berperilaku yang menjadi ciri khas tiap individu untuk hidup bekerja sama, baik dalam lingkungan keluarga, masyarakat, bangsa, dan negara. Individu yang berkarakter baik adalah individu yang bisa membuat keputusan dan siap mempertanggungjawabkan tiap akibat dari keputusan yang dibuat. Secara logika individu yang berkarakter akan melakukan tindakantindakan yang sesuai dengan tata aturan yang berlaku di masyarakat secara logis. Individu yang berkarakter kuat tidak mudah terpengaruh oleh sesuatu yang sifatnya merusak tatanan sistem di dalam kehidupan dirinya maupun lingkungannya.

Berkaitan dengan karakter, Lickona (1992, hlm. 53) menyebutkan komponen-komponen karakter yang dibagi dalam tiga komponen besar yaitu moral knowing, moral feeling dan moral action. Komponen tersebut dapat mengantarkan seseorang pada sebuah karakter yang baik.

\section{Pendidikan Karakter}

Pendidikan nilai karakter dapat dilihat pada dua latar, yaitu pada latar makro dan pada latar mikro. Latar makro bersifat nasional yang mencakup keseluruhan konteks perencanaan dan implementasi pembinaan nilai karakter yang melibatkan seluruh pemangku kepentingan. Secara makro pembinaan karakter terdiri dari tiga tahap yaitu: perencanaan, pelaksanaan dan evaluasi hasil.

Pada tahap perencanaan, dikembangkan perangkat karakter yang digali, dikristalisasikan, dan dirumuskan dengan menggunakan berbagai sumber, antara lain pertimbangan: 1) filosofis: Pancasila, UUD 1945, dan UU No. 20 tahun 2003 beserta ketentuan perundang-undangan turunannya; 2) teoretis, teori tentang otak, psikologis,
Pendidikan, nilai dan moral, serta sosiokultural; 3) empiris: berupa pengalaman dan praktik terbaik, antara lain tokoh-tokoh, satuan Pendidikan formal dan non-formal unggulan, pesantren, kelompok kultural, dll.

Pada tahap implementasi dikembangkan pengalaman belajar dan proses pembelajaran yang bermuara pada pembentukan karakter dalam diri peserta didik. Proses ini dilaksanakan melalui proses pemberdayaan dan pembudayaan sebagimana digariskan sebagai salahsatu prinsip penyelenggaraan Pendidikan nasional. Proses ini berlangsung dalam tiga pilar Pendidikan, yaitu dalam satuan Pendidikan formal dan non-formal, keluarga dan masyarakat. Dalam masing-masing pilar Pendidikan akan ada dua jenis pengalaman belajar yang dibangun melalui dua pendekatan yakni intervensi dan habituasi. Dalam intervensi dikembangkan suasana interaksi belajar dan pembelajaran yang sengaja dirancang untuk mencapai tujuan pembentukan karakter dengan menerapkan kegiatan yang terstruktur. Agar proses pembelajaran tersebut berhasil guna, peran pendidik sebagai sosok panutan sangat penting dan menentukan. Sementara dalam habituasi diciptakan situasi dan kondisi serta penguatan yang memungkinkan peserta didik pada satuan pendidikannya, rumahnya, dan lingkungan masyarakatnya membiasakan diri berperilaku sesuai nilai sehingga terbentuk karakter yang telah diinternalisasi dan dipersonalisasi dari dan melalui proses intervensi. Proses pemberdayaan dan pembudayaan yang mencakup pemberian contoh, pembelajaran, pembiasaan, dan penguatan harus dikembangkan secara sistemik, holistik dan dinamis.

Dalam konteks makro kehidupan berbangsa dan bernegara Indonesia, pelaksanaan Pendidikan karakter merupakan komitmen seluruh sektor kehidupan, bukan hanya sektor pendidikan nasional. Keterlibatan aktif dari sektor-sektor pemerintah lainnya, khususnya sektor keagamaan, kesejahteraan, pemerintahan, komunikasi dan informasi, kesehatan, hukum dan hak asasi manusia, serta pemuda dan olahraga juga sangat memungkinkan. 
Pada tahap evaluasi hasil, dilakukan asesmen program untuk perbaikan berkelanjutan yang dirancang dan dilaksanakan untuk mendeteksi aktualisasi karakter dalam diri peserta didik sebagai indikator bahwa proses pembudayaan dan pemberdayaan karakter itu berhasil dengan baik, menghasilkan sikap yang kuat, dan pikiran yang argumentatif.

Pada latar makro, program Pendidikan karakter dapat digambarkan sebagai berikut:

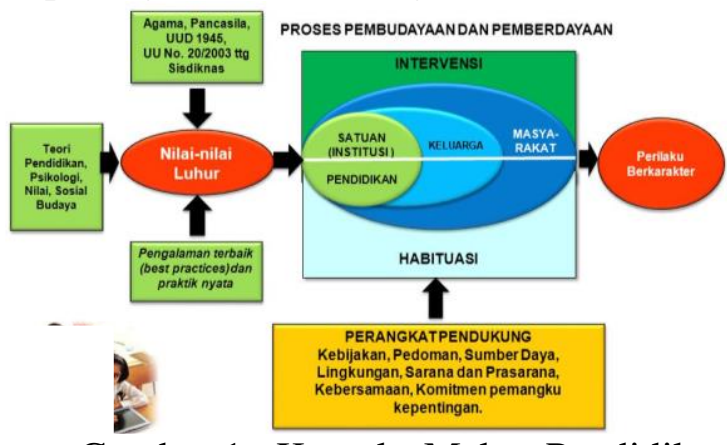

Gambar 1. Konteks Makro Pendidikan Karakter (Budimansyah, 2010)

Pada konteks mikro, Pendidikan karakter berpusat pada satuan Pendidikan formal dan non-formal secara holistik. Satuan Pendidikan formal dan non-formal merupakan wilayah utama yang secara optimal memanfaatkan dan memberdayakan semua lingkungan belajar yang ada untuk menginisiasi, memperbaiki, menguatkan, dan menyempurnakan secara terus menerus proses Pendidikan karakter. Pendidikan seharusnya melakukan upaya sungguh-sungguh dan senantiasa menjadi garis depan dalam upaya pembentukan karakter manusi Indonesia yang sesungguhnya.

Secara mikro pengembangan karakter dibagi dalam empat pilar, yaitu kegiatan belajar mengajar di kelas, kegiatan keseharian dalam bentuk pengembangan budaya satuan pendidikan formal dan non-formal; kegiatan kurikuler dan/ atau ekstrakurikuler, serta kegiatan keseharian di rumah dan masyarakat. Program pendidikan karakter pada konteks mikro dapat digambarkan sebagai berikut:

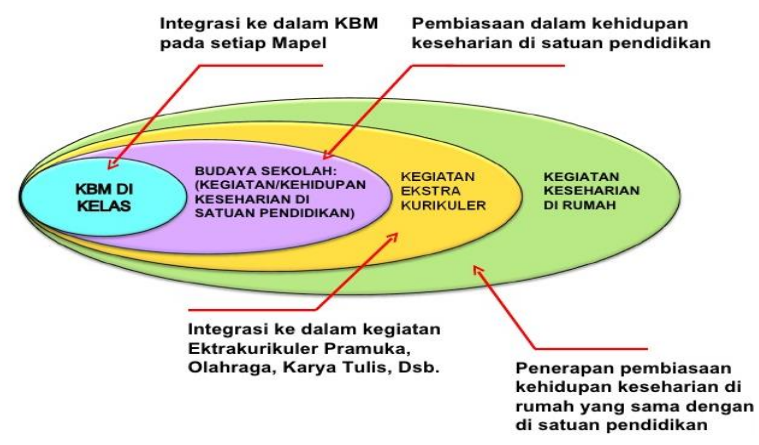

Gambar 2. Konteks Mikro Pendidikan Karakter (Budimansyah, 2010)

Bangsa Indonesia perlu melakukan pembinaan karakter dengan sungguh-sungguh, sistematik, dan berkelanjutan untuk membangkitkan dan menguatkan kesadaran serta keyakinan semua orang Indonesia bahwa tidak akan ada masa depan yang lebih baik tanpa membangun dan menguatkan karakter rakyat Indonesia. Dengan kata lain, tidak ada masa depan yang lebih baik yang bisa diwujudkan tanpa kejujuran, tanpa meningkatkan disiplin diri, tanpa kegigihan, tanpa semangat belajar yang tinggi, tanpa mengembangkan rasa tanggung jawab, tanpa memupuk persatuan di tengah-tengah kebhinekaan, tanpa semangat berkontribusi bagi kemajuan bersama, serta tanpa rasa percaya diri dan optimisme.

Sementara itu, Lickona (2004) menyebutkan adanya sepuluh nilai utama yang bisa ditanamkan oleh pihak sekolah. Kesepuluh nilai itu adalah, sebagai berikut:

1) Kebijaksanaan/ bijaksana (wisdom):

2) Keadilan/adil (justice)

3) Daya tahan (fortitude)

4) Kontrol diri (self-control)

5) Cinta (love)

6) Sikap positif (positive attitude)

7) Kerja keras (hard works)

8) Kepribadian yang utuh (integrity)

9) Perasaan berterimakasih (gratitude)

10) Kerendahan hati (humility)

Nilai-nilai karakter tersebut sangat layak ditanamkan dalam diri peserta didik di setiap lembaga pendidikan yang ada di Indonesia. Nilai karakter yang dikemukakan Lickona relevan dengan kondisi Indonesia yang beragam. Sebagai nilai universal, kesepuluh nilai itu memungkinkan untuk diterapkan 
dimanapun. Dalam konteks Pendidikan di Indonesia, setiap pendidikan karakter harus dijiwai nilai-nilai Pancasila secara utuh dan komprehensif, yaitu karakter peserta didik yang berketuhanan Yang Maha Esa, berkemanusiaan yang adil dan beradab, mengutamakan persatuan dan kesatuan bangsa, demokratis dan menjunjung tinggi hak asasi manusia, serta mengedepankan keadilan dan kesejahteraan bagi seluruh rakyat Indonesia (Samani dan Hariyanto, 2012). Selain itu, ketokohan seseorang sebagai pendidik di berbagai lingkungan pendidikan sangat penting dalam pendidikan karakter. Sebagai role model pendidikan memiliki peran penting. Campbell (2004:411) dan Willemse, Lunenberg \& Korthagen (2005: 207) menyatakan jika pendidik tidak memiliki kekuatan dan karakter maka mereka tidak bisa menjadi model panutan yang baik bagi peserta didik, apalagi bagi kelompok dan masyarakat. Demikian pula Weissbourd (2003:8), menyatakan pemodelan yang ditunjukkan pendidik, termasuk kepemimpinan moral, memberikan kontribusi secara signifikan dalam pengembangan karakter peserta didik. Hal ini menunjukkan bahwa peran pendidik sangat penting dalam pendidikan karakter peserta didik.

\section{PEMBAHASAN}

Dalam kegiatan belajar mengajar di kelas, pengembangan karakter dilaksanakan dengan menggunakan pendekatan terintegrasi dalam semua materi pembelajaran. Pendidikan agama dan kewarganegaraan karena memang misinya adalah mengembangkan nilai dan sikap, pengembangan karakter harus menjadi fokus utama yang dapat menggunakan berbagai strategi/ metode Pendidikan karakter. Untuk kedua materi pembelajaran tersebut, karakter dikembangkan sebagai dampak pembelajaran dan juga dampak pengiring. Sementara itu untuk materi pembelajaran lainnya, yang secara formal memiliki misi utama selain pengembangan karakter, wajib dikembangkan kegiatan yang memiliki dampak pengiring bagi berkembangnya karakter dalam diri peserta didik. Dalam hal ini, peserta didik, pendidik, dan tenaga kependidikan harus mau mengembangkan diri terus menerus (belajar secara disiplin sehingga mampu bersaing dan mengikuti perubahan).

Dalam lingkungan satuan pendidikan formal dan non-formal dikondisikan agar lingkungan fisik dan sosio-kultural satuan Pendidikan formal dan non-formal memungkinkan para peserta didik bersama dengan warga satuan Pendidikan formal dan non-formal lainnya terbiasa membangun kegiatan keseharian yang mencerminkan perwujudan karakter yang dituju. Dalam kegiatan ko-kurikuler atau kegiatan ekstrakurikuler perlu dikembangkan proses pembiasaan dan penguatan dalam rangka pengembangan karakter.

Di lingkungan keluarga dan masyarakat diupayakan terjadi proses penguatan dari orang tua/ wali serta tokoh-tokoh masyarakat terhadap perilaku berkarakter mulia yang dikembangkan di satuan pendidikan formal dan non-formal sehingga menjadi kegiatan keseharian di rumah dan di lingkungan masyarakat masing-masing. Hal ini dapat dilakukan lewat komite sekolah, pertemuan orang tua, kunjungan/ kegiatan orang tua/ wali yang berhubungan dengan kegiatan sekolah dan keluarga.

Pembinaan karakter harus diimplementasikan secara struktural dan kontekstual. Secara struktural artinya membangun karakter dimulai dari lingkungan keluarga sebagai lingkungan pendidikan informal, selanjutnya sekolah dan perguruan tinggi sebagai lingkungan pendidikan formal, dan selanjutnya di lingkungan masyarakat sebagai lingkungan pendidikan non-formal. Sementara aspek kontekstual terkait dengan nilai-nilai pokok yang diperlukan untuk membentuk kekuatan karakter, yang mana nilai-nilai pokok ini dapat diinternalisasikan pada pusat-pusat pendidikan karakter, yaitu lingkungan keluarga, lingkungan sekolah/ perguruan tinggi, dan lingkungan masyarakat.

Pembinaan karakter merupakan proses dan upaya seumur hidup yang perlu melibatkan pusat-pusat pendidikan karakter, baik lingkungan keluarga, lingkungan sekolah/ perguruan tinggi, dan lingkungan masyarakat. Umar (2018:20) pendidikan nilai karakter dapat 
berjalan dengan maksimal melalui pembelajaran jika peserta didik merasa nyaman dengan lingkungan belajarnya. Oleh sebab itu, lingkungan pendidikan karakter ini harus berjalan secara terintegrasi dan terpadu. Orang tua, guru, dosen, tokoh masyarakat, tokoh agama, tokoh adat, dan lain-lain memiliki tanggung jawab yang sama besarnya dalam melaksanakan pembinaan karakter.

a) Lingkungan Keluarga

Lingkungan keluarga adalah unit terkecil di masyarakat yang terdiri dari kepala keluarga dan beberapa orang yang berkumpul serta tinggal di suatu tempat di bawah satu atap dalam keadaan saling bergantung. Orang tua, guru, dan administrator sebagai pemangku kepentingan secara bersama-sama bergabung untuk mendorong siswa mewujudkan nilai-nilai baik dalam kehidupan peserta didik (Parker, Nelson, \& Burns, 2010; Trisiana, 2015; Wang, 2017).

Lingkungan keluarga memiliki fungsi pendidikan, yang mana keluarga menjadi wahana terbaik dalam proses sosialisasi dan pendidikan bagi anak-anak. Keluarga menjadi wahana untuk mendidik, mengasuh, dan mensosialisasikan sesuatu pada anak, mengembangkan kemampuan seluruh anggotanya agar dapat menjalankan fungsinya di masyarakat dengan baik, serta memberikan kepuasan dan lingkungan yang sehat guna tercapainya keluarga sejahtera. Keluarga merupakan aspek penting untuk menanamkan karakter pada anak sehingga anak mempunyai karakter yang baik.

b) Lingkungan Sekolah/ Perguruan Tinggi

Lingkungan sekolah yang merupakan lingkungan pendidikan formal, juga menentukan dalam perkembangan dan pembinaan karakter peserta didik. Bahkan sekolah dapat disebut sebagai lingkungan pendidikan kedua setelah keluarga yang berperan dalam pendidikan karakter pada seorang peserta didik. Hal ini cukup beralasan karena sekolah merupakan tempat khusus dalam menuntut berbagai ilmu pengetahuan.

Pembinaan karakter di lingkungan sekolah dapat diintegrasikan pada setiap mata pembelajaran. Materi pembelajaran yang berkaitan dengan norma atau nilai-nilai pada setiap mata pelajaran perlu dikembangkan, dieksplisitkan, dikaitkan dengan konteks kehidupan sehari-hari. Dengan demikian, pembelajaran nilai-nilai karakter tidak hanya pada tataran kognitif, tetapi menyentuh pada internalisasi dan pengalaman nyata dalam kehidupan peserta didik sehari-hari di masyarakat.

Satu hal yang penting dalam pembelajaran karakter adalah komunikasi efektif (Modell, 1996). Selain itu, peran penting pendidik dengan sikap dan perilaku yang baik akan menunjang pendidikan karakter agar peserta didik memiliki ketertarikan dalam setiap aktivitas belajarnya. (Ferguson \& Houghton, 1992)

c) Lingkungan Masyarakat

Masyarakat merupakan lingkungan pendidikan informal yang turut berperan dalam terselenggaranya proses pembinaan karakter. Setiap individu sebagai anggota dari masyarakat harus bertanggung jawab dalam menciptakan suasana yang nyaman dan mendukung.

Dalam pendidikan anak, orang tua hendaknya memilih lingkungan yang mendukung pendidikan anak dan menghindari lingkungan masyarakat yang kurang baik. sebab, ketika anak atau peserta didik berada di lingkungan masyarakat yang kurang baik, perkembangan karakter atau kepribadian anak tersebut dapat menjadi kurang baik. orang tua harus memilih lingkungan masyarakat yang sehat dan cocok sebagai tempat tinggal orang tua beserta anaknya. Demikian pula sekolah sebagai lingkungan pendidikan formal, juga perlu memilih lingkungan masyarakat yang baik sehingga ikut mendukung proses pendidikan.

Karena pentingnya peran masyarakat sebagai pusat pendidikan karakter, maka setiap individu sebagai anggota masyarakat harus menciptakan suasana yang nyaman demi keberlangsungan proses pendidikan yang terjadi didalamnya. Di Indonesia, dikenal adanya konsep pendidikan berbasis masyarakat (community based education) sebagai upaya untuk memberdayakan masyarakat dalam 
penyelenggaraan pendidikan. Meskipun konsep ini lebih sering dikaitkan dengan sekolah sebagai pendidikan formal, dengan adanya konsep ini sekaligus menunjukkan bahwa kepedulian masyarakat sangat dibutuhkan, serta keberadaannya sangat berpengaruh terhadap pelaksanaan pendidikan di sekolah.

Dalam penyelenggaraan pendidikan karakter, dibutuhkan keterpaduan pusat pendidikan karakter di atas, yaitu lingkungan keluarga, sekolah/ perguruan tinggi, dan masyarakat. Kesemuanya perlu berada dalam suatu kekompakan melalui jalinan komunikasi dan kolaborasi yang harmonis dalam mendukung program-program pembinaan karakter.

\section{KESIMPULAN}

Pendidikan karakter bukanlah suatu tugas yang mudah dilakukan jikaa tidak melibatkan semua komponen dalam dunia pendidikan. Demikian pula dukungan dari semua pihak, baik lingkungan keluarga, sekolah, dan masyarakat serta dukungan pemerintah menjadi faktor penting dalam pendidikan karakter. Di Indonesia, tugas pendidikan karakter harus secara jelas ditekankan dalam pembelajaran di sekolah. Hal ini dapat dilakukan dalam program integrasi karakter dalam setiap kegiatan pembelajaran di kelas dan di luar kelas. Demikian pula, kegiatan di luar sekolah yaitu interaksi peserta didik di lingkungan keluarga dan masyarakat. Peran pada lingkungan ini perlu dilakukan oleh orang tua dan tokoh masyarakat sebagai role model.

\section{DAFTAR PUSTAKA}

Budimansyah, D. (2010). Penguatan Pendidikan Kewarganegaraan Untuk Membangun Karakter Bangsa, Bandung: Widya Aksara Press.

Budimansyah, D. (2012). Perancangan Pembelajaran Berbasis Karakter. Bandung: Widya Aksara Press.

Campbell, E. (2004), Ethical Base of Moral Agency in Teaching, Teacher and Teaching: Theory and Practice, 10 (4), 409-428.

Ferguson, Elizabeth., \& Houghton, Stephen. (1992). "The effects of Contingent Teacher Praise, as Specified by Canter's Assertive Discipline Programme, on children's on - task behaviour", Educational Studies, Vol.18 (1): 83-93.

Modell, H.I., (1996), "Preparing Students To Participate In An Active Learning Environment", Advances in Physiology Education, 270, pp.69-77.

Nucci, L.V., \& Narvaez, D. (2008). Handbook Pendidikan Moral dan Karakter. New. York: Taylor \& Francis

Parker, D. C., Nelson, J. S., \& Burns, M. K. (2010). Comparison of correlates of classroom behavior problems in schools with and without a school-wide character education program. Psychology in the Schools, 47(8), 817-827.

Students Through History. University of Toronto.

Umar, M., Hakam. K.A., \& Somad, M.A. (2018). Peace Values in Learning Process (A Descriptive study based on Student Experiences), Advances in Social Sciences, Education and Humanities Research, Vol. 253, p. 20-23.

Wang, L. (2017). What Does It Mean to Be Canadian? Building National Identity for Secondary

Willemse, M., Lunenberg, M. \& Korthagen, F. (2005), "Values in Education: A Challenge for Teacher Educators". Teaching and Teacher Education, 21 (2), 205-217. 